\title{
USULAN PERBAIKAN POSTUR KERJA UNTUK MENGURANGI \\ BEBAN KERJA PROSES MANUAL MATERIAL HANDLING DENGAN METODE RULA REBA QEC (Studi Kasus Pengemasan Herbisida di PT. Petrokimia Kayaku Pabrik 3)
}

\author{
Gatot Basuki HM, Narto
}

Program Studi Teknik Industri Institut Teknologi Adhi Tama Surabaya (ITATS) e-mail: gatotbasukihm@itats.ac.id, nartonazriel@gmail.com

\begin{abstract}
ABSTRAK
Kondisi sikap kerja bagian pengemasan produk herbisida di PT. Petrokimia Kayaku Pabrik 3 sering kali pekerja mengeluh pada bagian anggota tubuh. Hal ini disebabkan oleh penanganan material handling saat proses pemindahan produk herbisida dari line robot di pindahkan ke atas pallet dengan mengangkat langsung produk herbisida yang sudah di kemas dalam karto box. Dengan kuesioner Nordic Body Map untuk mengukur 27 jenis keluhan tubuh, selanjutnya menggunakan Metode RULA sebagai alat analisis untuk mengurangi resiko musculoskeletal disorders pada tubuh bagian atas, sedangkan metode REBA digunakan untuk menganalisis postur tubuh bagian bawah. Quick Exposure Check (QEC) adalah metode yang digunakan untuk mengetahui risiko cidera gangguan otot rangka (musculoskeletal disorder) yang menitik beratkan pada tubuh bagian atas. Tujuan penelitian untuk mengetahui sikap kerja pekerja dan melakukan penilaian postur kerja serta memberikan usulan perbaikan metode kerja pada proses Manual Material Handling line robot bagian pengemasan produk herbisida. Hasil analisis menunjukan sikap pekerja belum memberikan kesiapan untuk merespon yang sifatnya positif atau negatif terhadap obyek dan situasi. perbaikan postur kerja hasil perhitungan yang dilakukan dengan metode RULA dari kondisi saat ini skor 7 menjadi skor 4, dimana usulan berupa perbaikan postur kerja yang ergonomi yaitu operator berdiri dengan posisi tegak. Kemudian menambahkan alat bantu kerja berupa pallet leveller sping dan U-Lift Roll-In Lift Table agar operator tidak perlu membungkuk ketika meletakkan karton box ke atas pallet. Sehingga dengan usulan ini grand score RULA dapat turun menjadi 4 dan termasuk dalam kategori level risiko rendah (perubahan mungkin diperlukan), grand score REBA dapat turun menjadi 2.
\end{abstract}

Kata kunci: Musculoskeletal Disorder, RULA, REBA, QEC.

\begin{abstract}
Conditions of work attitude for the packaging section of herbicide products at PT. Petrochemical Kayaku Factory 3 often workers complain about limbs. This is caused by the handling of material handling when the process of removing herbicide products from the robot line is moved to the pallet by directly lifting the herbicide product that has been packaged in a cardboard box. With the Nordic Body Map questionnaire to measure 27 types of body complaints, then using the RULA Method as an analytical tool to reduce the risk of musculoskeletal disorders in the upper body, while the REBA method is used to analyze the lower body posture. Quick Exposure Check (QEC) is a method used to determine the risk of injury to skeletal muscle disorders (musculoskeletal disorder) that focuses on the upper body. The research objective is to determine the work attitude of workers and to assess work posture and to propose improvements to work methods in the process of Manual Material Handling line robots for packaging herbicide products. The analysis shows that workers' attitudes have not provided readiness to respond positively or negatively to objects and situations. work posture improvement results of calculations performed by the RULA method from the current condition score 7 to score 4, where the proposal is in the form of improved work posture that is ergonomic that is the operator standing in an upright position. Then add work tools in the form of pallet leveler sping and U-Lift Roll-In Lift Table so that the operator does not need to bend when placing the carton box onto the pallet. So with this proposal the RULA grand score can go down to 4 and fall into the low risk level category (changes may be needed), the REBA grand score can go down to 2.
\end{abstract}

Keywords: Musculoskeletal Disorder, RULA, REBA, QEC. 


\section{PENDAHULUAN}

Tingginya tingkat produktivitas akan mengakibatkan semakin besar risiko kerja yang akan ditimbulkan. Perkembangan ilmu pengetahuan dan teknologi membuat industriindustri berlomba-lomba untuk melakukan efisiensi dan meningkatkan produktivitas dengan menggunakan alat-alat produksi yang semakin canggih, semakin canggihnya peralatan kerja yang digunakan, maka semakin banyak pula produk yang dapat dihasilkan akan tetapi kebutuhan manusia sebagai sumber tenaga kerja hanya sedikit. Keterbatasan kemampuan perusahaan dalam pengadaan mesin dan peralatan produksi mendorong industri menggunakan mesin dan peralatan manual dalam proses produksi [1]. Tenaga kerja manusia merupakan faktor dominan dalam proses produksi di industri manufaktur. Perpindahan material dari departemen ke departemen yang lain adalah masalah utama dalam proses industri manufaktur. Peran dominan manusia sebagai sumber tenaga kerja dalam aktivitas pemindahan material secara manual (Manual Material Handling) untuk menjalankan proses produksi. Manual Material Handling adalah proses membawa bahan baku atau produk secara manual pada industri [2]. Lebih luas Manual Material Handling merupakan kegiatan transportasi untuk mengangkat dan memindahkan barang berupa material bahan baku dan produk secara manual dengan tenaga manusia [3]. Tingginya risiko yang di alami oleh pekerja dalam melakukan kegiatan manual material handling seperti risiko penyakit tulang belakang (low back pain) akibat melakukan aktivitas memindahkan dan mengangkat barang secara manual dengan posisi tubuh yang salah, mengakibatkan cidera pada bagian tubuh. [4]. Tingkat fleksibilitas yang tinggi merupakan keunggulan dari penggunaan Manual Material Handling dibanding dengan peralatan produksi yang lain seperti pemanfaatan peralatan produksi berbasis robotic, akan tetapi hal tersebut membutuhkan penanganan dan pemeliharaan yang khusus. Penggunaan prosedur dan pengawasan yang tepat akan membantu pekerja dalam melakukan setiap pekerjaan yang dilakukan dalam proses produksi. Industri manufaktur menggunakan Manual Material Handling karena tingginya tingkat fleksibilitas gerakan dalam penanganan bahan atau produk [5].

Kondisi sikap kerja bagian pengemasan produk herbisida di PT. Petrokimia Kayaku Pabrik 3 dalam proses produksi sering kali pekerja mengeluh pada bagian anggota tubuh. Hal ini disebabkan oleh penanganan material handling saat proses pemindahan produk herbisida dari line robot di pindahkan ke atas pallet dengan mengangkat langsung produk herbisida yang sudah di kemas dalam karton. Posisi pallet yang berada dibawah mengakibatkan posisi tubuh pekerja harus membungkuk untuk bisa meletakan produk tersebut. Pekerjaan yang dilakukan berulang-ulang mengakibatkan posisi kerja yang tidak ergonomi sehingga mengakibatkan tingkat kelelahan yang tinggi. Dari hasil penyebaran kuesioner Nordic Body Map pada 8 pekerja Manual Material Handling menunjukkan keluhan pada berbagai anggota tubuh setelah dan sebelum bekerja. Keluhan pekerja pada bagian tubuh akibat kegiatan Manual Material Handling diantara yaitu adanya rasa sakit pada leher bagian atas dan bawah, bahu sebelah kanan dan bagian punggung. Adanya keluhan yang dirasakan pekerja tersebut menunjukkan bahwa kegiatan Manual Material Handling pada bagian pengemasan di PT. Petrokimia Kayaku Pabrik 3 menimbulkan rasa tidak nyaman pada bagian Musculoskeletal. Salah satu upaya yang dapat dilakukan untuk mengatasi hal ini adalah memperbaiki metode kerja. Keluhan musculoskeletal merupakan kerusakan pada otot, saraf, tendon, ligament, persendian, kartilago, dan discus invertebralis. Kerusakan pada otot dapat berupa ketegangan otot, inflamasi, dan degenerasi. Sedangkan kerusakan pada tulang dapat berupa memar, mikro faktor, patah, atau terpelintir [6]. Musculoskeletal Disorder adalah gangguan pada bagian otot skeletal yang disebabkan oleh otot menerima beban statis secara berulang-ulang dalam jangka waktu lama, mengakibatkan keluhan berupa kerusakan pada sendi, ligamen dan tendon [7]. 
Keluhan muskuloskeletal adalah keluhan yang berada pada bagian otot skeletal atau otot rangka yang dirasakan oleh seseorang mulai dari keluhan sangat ringan hingga sangat sakit [8].

Rapid Upper Limb Assessment (RULA) merupakan metode yang dikembangkan dalam bidang ergonomi untuk mengukur dan menilai posisi kerja tubuh bagian atas [9]. RULA menyediakan sebuah perhitungan yang mudah terhadap tingkat musculoskeletal loads dari pekerjaan dimana operator memiliki risiko dari beban leher dan anggota bagian atas [10]. RULA dan memberikan usulan perbaikan sikap kerja untuk mengurangi resiko musculoskeletal disorders [11]. RULA menilai postur, gaya, dan gerakan suatu aktivitas kerja yang berkaitan dengan penggunaan anggota tubuh bagian atas, sedangkan REBA digunakan untuk menilai postur leher, punggung, lengan, pergelangan tangan dan kaki [12]. Metode REBA (Rapid Entire Body Assessment) digunakan untuk menganalisis postur tubuh pekerja bagian produksi [13]. Rapid Entire Body Assesment (REBA) metode yang digunakan secara cepat untuk menilai postur seorang pekerja, input yang digunakan dalam metode REBA adalah pengambilan data postur pekerja menggunakan foto, penentuan sudut pada batang tubuh, leher, kaki, lengan atas, lengan bawah dan pergelangan tangan [14]. Quick Exposure Check (QEC) adalah metode untuk mengetahui risiko cidera gangguan otot rangka (musculoskeletal disorder) yang menitik beratkan pada tubuh bagian atas yaitu punggung, leher, lengan atau bahu, dan pergelangan tangan [15]. QEC membantu untuk mencegah terjadinya cedera otot rangka pada saat bekerja musculoskeletal disorders (MSDs) yang dialami oleh pekerja dengan penanganan material secara manual, seperti gerak repetitive, gaya tekan, postur yang salah, dan durasi kerja [16].

Tujuan penelitian ini untuk mengetahui sikap kerja pekerja dan melakukan penilaian postur kerja serta memberikan usulan perbaikan metode kerja pada proses Manual Material Handling line robot departemen pengemasan produk herbisida di PT. Petrokimia Kayaku pabrik 3. Hasil akhir penelitian adalah usulan perbaikan sikap kerja, dengan usulan ini diharapkan para pekerja dapat melakukan pekerjaan dengan baik dan mengurangi kelelahan yang dialami saat bekerja.

\section{METODE PENELITIAN}

Langkah pertama penelitian ini yaitu melakukan kuesioner terhadap para pekerja bagian pengemasan produk herbisida. Kuesioner disusun berdasarkan Nordic Body Map merupakan kuesioner berisi data bagian tubuh yang dikeluhkan oleh para pekerja, untuk mengetahui ketidaknyamanan pekerja. Kuesioner ini paling sering digunakan karena sudah terstandarisasi dan tersusun rapi.

Langkah kedua yaitu analisis postur kerja dengan metode RULA, dirancang untuk kemudahan tanpa memerlukan alat yang sulit digunakan. Menggunakan tabel skor RULA, peneliti akan menetapkan skor untuk masing-masing daerah tubuh berikut: lengan atas, lengan bawah, pergelangan tangan, leher, batang, dan kaki. Setelah itu, dari hasil skor di beberapa bagian tubuh itu ditambahkan dan didapatkan hasil skor akhir yang nantinya akan disimpulkan menjadi jenis pekerjaan yang di lakukan termasuk dalam beberapa kategori yaitu skor 1-2 risiko diabaikan, skor 3-4 risiko rendah, skor 5-6 risiko sedang, sedangkan skor 6+ adalah kategori Sangat berisiko. Tahapan analisis metode RULA yaitu (1) Pengambilan data postur pekerja dengan menggunakan bantuan (2) Video atau foto (3) Observasi dan pilih postur yang akan dianalisis (4) Scoring and recording the posture (5) Action level (6) Analisa postur (7) Saran perbaikan.

Langkah ketiga adalah Pengolahan data REBA (Rapid Entire Body Assessment) didapatkan dari perhitungan sudut-sudut postur tubuh yang dilakukan oleh operator pada proses Manual Material Handling. Sudut-sudut ini didapatkan dari data foto yang sudah diambil, dengan metode ini memungkinkan perusahaan melakukan perbaikan terhadap 
tempat kerja di bagian Manual Material Handling pada bagian pengemasan produk herbisida. Pengolahan data akan di hitung manual pada tabel skor REBA yang sudah ada yang terbagi dalam postur tubuh A dan postur tubuh B dan juga memakai software ErgoFellow untuk membantu menentukan skor REBA.

Langkah terakhir yaitu pengumpulan data yang dilakukan adalah dengan penyebaran kuesioner QEC pada pekerja yang bekerja pada bagian Manual Material Handling dan juga kepada peneliti yang melakukan penelitian pada bagian tersebut. Kuesioner QEC untuk peneliti dan pekerja berbeda, akan tetapi keduanya digunakan untuk menganalisis kondisi suatu stasiun kerja. Kuesioner pengamat lebih menitik beratkan kepada postur tubuh yang terbentuk oleh pekerja ketika melakukan pekerjaannya. Kuesioner untuk pekerja lebih menitik beratkan kepada yang dirasakan oleh pekerja ketika melakukan pekerjaannya seperti beban yang harus diangkat dan juga durasi kerja. Setelah diperoleh data kuesioner, kemudian dihitung exposure score pada setiap anggota tubuh yang diamati yaitu punggung, bahu/lengan, pergelangan tangan, dan leher. Selanjutnya menghitung exposure level untuk menentukan tindakan apa yang dilakukan berdasarkan dari hasil perhitungan total exposure score.

\section{HASIL DAN PEMBAHASAN}

Identifikasi terhadap musculoskeletal disorders (MSDs) terhadap pekerja menggunakan kuesioner Nordic Body Map berupa peta tubuh yang berisikan data bagian tubuh yang dikeluhkan oleh para pekerja. Dari hasil penyebaran kuesioner ini pada 8 pekerja di bagian Manual Material Handling maka didapatkan hasil sebagai berikut.

Tabel 1. Hasil Kuesioner Nordic Body Map Pekerja Pengemasan Herbisida

\begin{tabular}{|c|c|c|c|c|c|}
\hline \multirow{2}{*}{ No. } & \multirow{2}{*}{ Jenis Keluhan } & \multicolumn{4}{|c|}{ Jumlah Keluhan } \\
\hline & & Tidak Sakit & Agak Sakit & Sakit & Sangat Sakit \\
\hline 0 & Sakit/kaku di leher bagian atas & 2 & 0 & 0 & 6 \\
\hline 1 & Sakit/kaku di leher bagian bawah & 2 & 0 & 0 & 6 \\
\hline 2 & Sakit di bahu kiri & 2 & 1 & 3 & 2 \\
\hline 3 & Sakit di bahu kanan & 1 & 1 & 3 & 3 \\
\hline 4 & Sakit pada lengan atas kiri & 1 & 2 & 4 & 1 \\
\hline 5 & Sakit di punggung & 2 & 0 & 2 & 4 \\
\hline 6 & Sakit pada lengan atas kanan & 2 & 3 & 2 & 1 \\
\hline 7 & Sakit pada pinggang & 2 & 3 & 2 & 1 \\
\hline 8 & Sakit pada bokong & 5 & 2 & 0 & 1 \\
\hline 9 & Sakit pada pantat & 5 & 2 & 0 & 1 \\
\hline 10 & Sakit pada siku kiri & 6 & 1 & 0 & 1 \\
\hline 11 & Sakit pada siku kanan & 7 & 1 & 0 & 0 \\
\hline 12 & Sakit pada lengan bawah kiri & 5 & 1 & 1 & 1 \\
\hline 13 & Sakit pada lengan bawah kanan & 6 & 1 & 0 & 1 \\
\hline 14 & Sakit pada pergelangan tangan kiri & 4 & 2 & 0 & 2 \\
\hline 15 & Sakit pada pergelangan tangan kanan & 3 & 3 & 0 & 2 \\
\hline 16 & Sakit pada tangan kiri & 1 & 6 & 0 & 1 \\
\hline 17 & Sakit pada tangan kanan & 2 & 5 & 0 & 1 \\
\hline 18 & Sakit pada paha kiri & 4 & 1 & 2 & 1 \\
\hline 19 & Sakit pada paha kanan & 4 & 1 & 2 & 1 \\
\hline 20 & Sakit pada lutut kiri & 3 & 1 & 2 & 2 \\
\hline 21 & Sakit pada lutut kanan & 3 & 1 & 2 & 2 \\
\hline 22 & Sakit pada betis kiri & 2 & 4 & 1 & 1 \\
\hline 23 & Sakit pada betis kanan & 2 & 3 & 2 & 1 \\
\hline 24 & Sakit pada pergelangan kaki kiri & 6 & 1 & 1 & 0 \\
\hline 25 & Sakit pada pergelangan kaki kanan & 5 & 1 & 1 & 1 \\
\hline 26 & Sakit pada kaki kiri & 2 & 4 & 1 & 1 \\
\hline 27 & Sakit pada kaki kanan & 3 & 4 & 1 & 0 \\
\hline
\end{tabular}

Dari tabel di atas dapat diketahui bahwa keluhan yang terasa sangat sakit pada 8 orang pekerja dirasakan pada bagian tubuh yaitu sangat sakit di leher bagian atas, sangat sakit di leher bagian bawah, sangat sakit di bahu kanan, sangat sakit di punggung. Sedangkan jumlah dan presentase keluhan yang Sangat Sakit yang dirasakan oleh pekerja bagian pengemasan herbisida disajikan pada tabel berikut. 
Tabel 2. Jumlah dan Presentase Keluhan yang Sangat Sakit

\begin{tabular}{lcc}
\hline \multicolumn{1}{c}{ Jenis Keluhan } & Jumlah & Presentase \\
\hline Sakit/kaku di leher bagian atas & 6 & $75 \%$ \\
Sakit/kaku di leher bagian bawah & 6 & $75 \%$ \\
Sakit di bahu kanan & 3 & $37.5 \%$ \\
Sakit di punggung & 4 & $50 \%$ \\
\hline
\end{tabular}

RULA (Rapid Upper Limb Assessment) didapatkan dari perhitungan sudut-sudut postur tubuh bagian atas yang dilakukan oleh operator pada proses Manual Material Handling. Sudut-sudut ini didapatkan dari data foto yang sudah diambil. Tahap awal adalah melakukan assessment postur tubuh pekerja terhadap stasiun kerja, dan menganalisa foto hasil dari pengamatan.

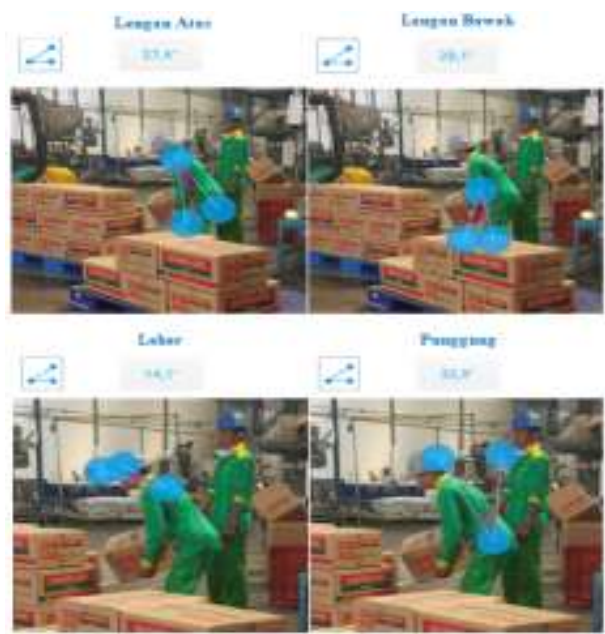

Gambar 1. Besar Sudut Pada Postur Kerja Operator dengan Metode RULA

Dari gambar di atas terlihat bahwa operator sedang melakukan kegiatan proses Manual Material Handling dengan postur agak membungkuk dalam posisi berulang-ulang.

Tabel 3. Skor RULA Tabel A

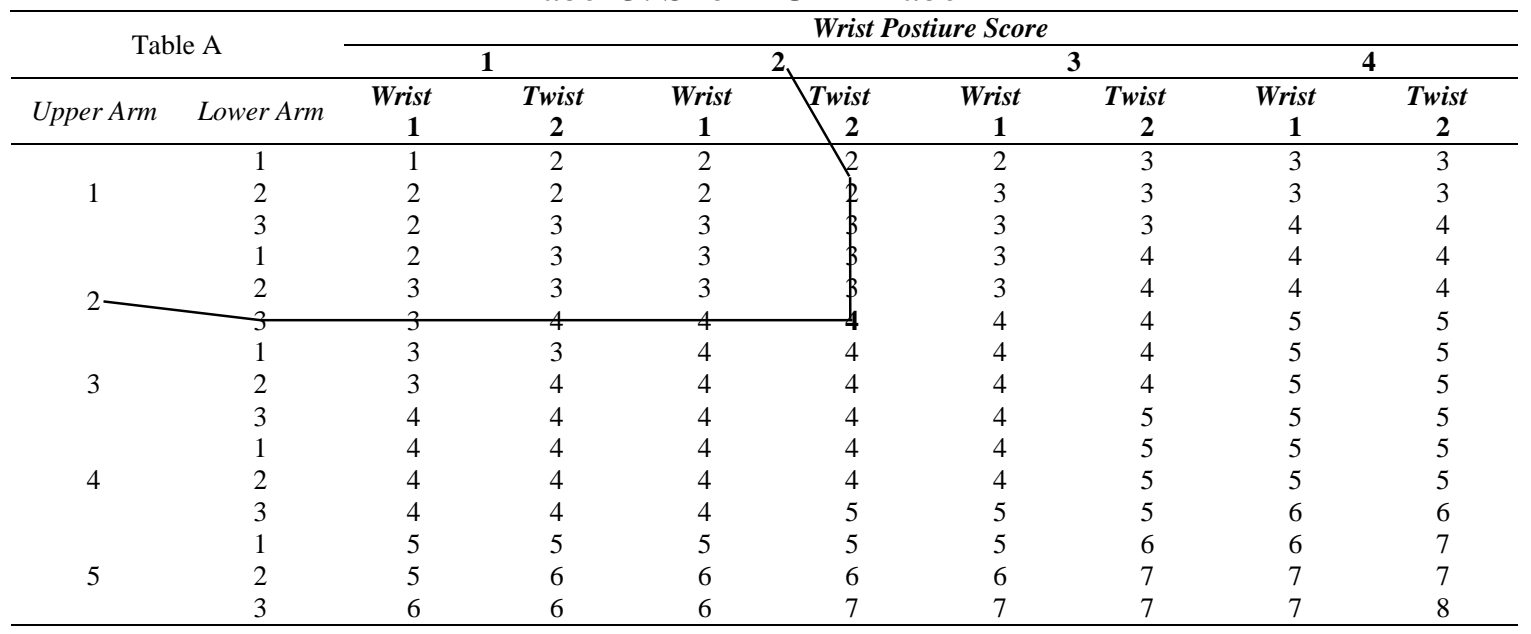

Skor untuk tabel A adalah sebesar 4. Untuk skor penggunaan otot, terjadi aktivitas yang berulang 4 kali per menit, maka diberi tambahan skor 1 . Sedangkan skor beban, beban yang ada pada proses adalah per 1 box $=20$ liter bila dikonversi menjadi $20 \mathrm{~kg}$ karena massa jenis air $=1 \mathrm{~kg} /$ liter, maka diberi skor 3 karena terjadi berulang. Skor baris Tabel C, Hasil akhir untuk kolom pada tabel C adalah $4+1+3=8$. 
Tabel 4. Skor RULA Tabel B

\begin{tabular}{|c|c|c|c|c|c|c|c|c|c|c|c|c|}
\hline \multirow{4}{*}{$\begin{array}{c}\text { Neck } \\
\text { Posture } \\
\text { Score }\end{array}$} & \multicolumn{12}{|c|}{ Trunk Posture Score } \\
\hline & \multicolumn{2}{|c|}{1} & \multicolumn{2}{|c|}{2} & \multicolumn{2}{|c|}{3} & \multicolumn{2}{|c|}{4} & \multicolumn{2}{|c|}{5} & \multicolumn{2}{|c|}{6} \\
\hline & \multicolumn{2}{|c|}{ Legs } & \multicolumn{2}{|c|}{ Legs } & \multicolumn{2}{|c|}{ Legs } & \multicolumn{2}{|c|}{ Ifegs } & \multicolumn{2}{|c|}{ Legs } & \multicolumn{2}{|c|}{ Legs } \\
\hline & 1 & 2 & 1 & 2 & 1 & 2 & & 2 & 1 & 2 & 1 & 2 \\
\hline 1 & 1 & 3 & 2 & 3 & 3 & 4 & 5 & 5 & 6 & 6 & 7 & 7 \\
\hline$z$ & 2 & 2 & 2 & 3 & 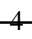 & 5 & 5 & 5 & 6 & 7 & 7 & 7 \\
\hline 3 & 3 & 3 & 3 & 4 & 4 & 5 & 5 & 6 & 6 & 7 & 7 & 7 \\
\hline 4 & 5 & 5 & 5 & 6 & 6 & 7 & 7 & 7 & 7 & 7 & 8 & 8 \\
\hline 5 & 7 & 7 & 7 & 7 & 7 & 8 & 8 & 8 & 8 & 8 & 8 & 8 \\
\hline 6 & 8 & 8 & 8 & 8 & 8 & 8 & 8 & 9 & 9 & 9 & 9 & 9 \\
\hline
\end{tabular}

Skor untuk tabel B adalah sebesar 5. Untuk skor penggunaan otot, terjadi aktivitas yang berulang 4 kali per menit, maka diberi tambahan skor 1.Sedangkan skor beban, beban yang ada pada proses adalah per 1 box $=20$ liter bila dikonversi ke $\mathrm{kg}$ menjadi $20 \mathrm{~kg}$ karena massa jenis air $=1 \mathrm{~kg} / \mathrm{liter}$, maka diberi skor 3 karena terjadi berulang. Skor kolom tabel C. hasil akhir untuk baris pada tabel $\mathrm{C}$ adalah $5+1+3=9$.

Setelah didapatkan skor tabel A dan tabel B, maka diperlukan skor akhir dari kedua skor tabel tersebut. Skor akhir ini dapat ditentukan menggunakan tabel C untuk menghitung skor akhir, berikut ini adalah skor akhir dari tabel A dan tabel B.

Tabel 5. Skor RULA Tabel C

\begin{tabular}{|c|c|c|c|c|c|c|c|c|}
\hline \multirow{2}{*}{\multicolumn{2}{|c|}{ Table C }} & \multicolumn{7}{|c|}{ Neck, Trunk and Legs Score } \\
\hline & & 1 & 2 & 3 & 4 & 5 & 6 & $7+$ \\
\hline \multirow{8}{*}{ 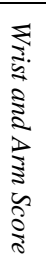 } & 1 & 1 & 2 & 3 & 3 & 4 & 5 & $\$$ \\
\hline & 2 & 2 & 2 & 3 & 4 & 4 & 5 & $\$$ \\
\hline & 3 & 3 & 3 & 3 & 4 & 4 & 5 & $\phi$ \\
\hline & 4 & 3 & 3 & 3 & 4 & 5 & 6 & $\phi$ \\
\hline & 5 & 4 & 4 & 4 & 5 & 6 & 7 & 7 \\
\hline & 6 & 4 & 4 & 5 & 6 & 6 & 7 & 7 \\
\hline & 7 & 5 & 5 & 6 & 6 & 7 & 7 & 7 \\
\hline & $8+$ & 5 & 5 & 6 & 7 & 7 & 7 & $\rightarrow$ \\
\hline
\end{tabular}

Berdasarkan tabel di atas maka diperoleh bahwa skor pada tabel $\mathrm{C}$ adalah 7, maka level risiko dari kegiatan Manual Material Handling tersebut masuk dalam level kategori sangat berisiko dan perlu segera dilakukan perubahan sekarang untuk postur kerja yang dilakukan.

Selanjutnya yaitu pengolahan data REBA (Rapid Entire Body Assessment) didapatkan dari perhitungan sudut-sudut postur tubuh bagian bawah yang dilakukan oleh operator pada proses Manual Material Handling.

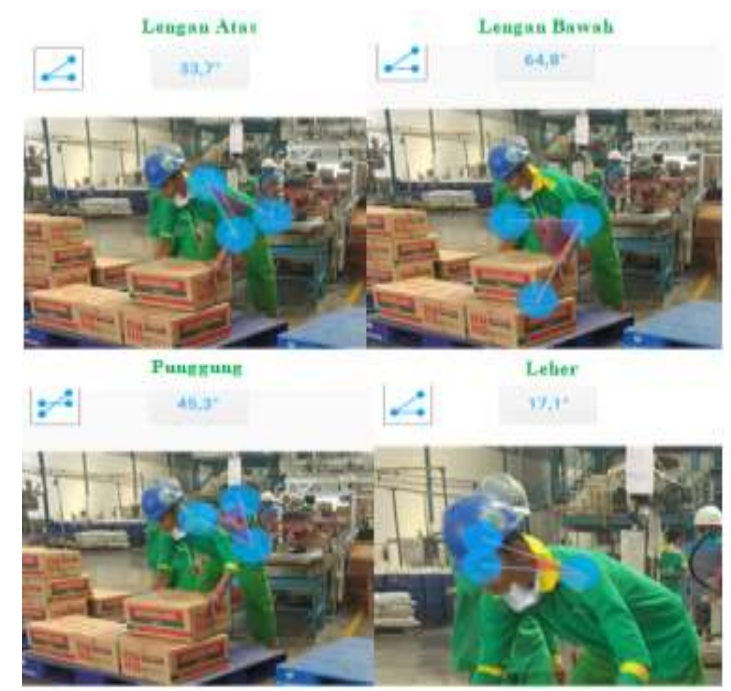

Gambar 2. Besar Sudut pada Postur Kerja Operator dengan Metode REBA 
Tabel 6. Skor REBA Grup A

\begin{tabular}{|c|c|c|c|c|c|c|c|c|c|c|c|c|c|}
\hline \multicolumn{14}{|c|}{ Leher } \\
\hline \multirow{2}{*}{\multicolumn{2}{|c|}{ Kaki }} & \multicolumn{4}{|c|}{1} & \multicolumn{4}{|c|}{2} & \multicolumn{4}{|c|}{3} \\
\hline & & 1 & & 3 & 4 & 1 & 2 & 3 & 4 & 1 & 2 & 3 & 4 \\
\hline \multirow{5}{*}{ 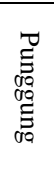 } & 1 & 1 & & 3 & 4 & 1 & 2 & 3 & 4 & 3 & 3 & 5 & 6 \\
\hline & 2 & 2 & & 4 & 5 & 3 & 4 & 5 & 6 & 4 & 5 & 6 & 7 \\
\hline & 3 & 2 & & 5 & 6 & 4 & 5 & 6 & 7 & 5 & 6 & 7 & 8 \\
\hline & 4 & 3 & 5 & 6 & 7 & 5 & 6 & 7 & 8 & 6 & 7 & 8 & 9 \\
\hline & 5 & 4 & 6 & 7 & 8 & 6 & 7 & 8 & 9 & 7 & 8 & 9 & 9 \\
\hline
\end{tabular}

Skor Grup A berdasarkan tabel di atas adalah 4. Sedangkan beban yang ada pada proses adalah per 1 box $=20$ liter bila dikonversi menjadi $20 \mathrm{~kg}$ karena massa jenis air $=$ $1 \mathrm{~kg} / \mathrm{liter}$, maka diberi skor 2. Sehingga total skor untuk Grup A adalah $4+2=6$.

Tabel 7. Skor REBA Grup B

\begin{tabular}{|c|c|c|c|c|c|c|c|}
\hline \multicolumn{8}{|c|}{ Lengan Bawah } \\
\hline \multicolumn{3}{|c|}{1} & \multicolumn{3}{|c|}{2} & \multirow{2}{*}{\multicolumn{2}{|c|}{ Pergelangan Tangan }} \\
\hline 1 & 2 & 3 & 1 & 2 & 3 & & \\
\hline 1 & 䍵 & 2 & 1 & 2 & 3 & 1 & \\
\hline 1 & 2 & 3 & 2 & 3 & 4 & -2 & $\stackrel{\tilde{\Xi}}{ \pm}$ \\
\hline 3 & 4 & 5 & 4 & 5 & 6 & 3 & $\bar{\longleftarrow}$ \\
\hline 4 & 5 & 5 & 5 & 6 & 7 & 4 & ప్ర్ల్ \\
\hline 6 & 7 & 8 & 7 & 8 & 8 & 5 & बृ \\
\hline 7 & 8 & 8 & 8 & 9 & 9 & 6 & \\
\hline
\end{tabular}

Skor Grup B berdasarkan tabel di atas adalah 2. Sedangkan skor genggaman masuk kategori pegangan kurang baik meskipun dapat digunakan, maka diberi skor 2. Sehingga total skor untuk Grup B adalah $2+2=4$. Setelah didapatkan skor grup A dan grup B, maka diperlukan skor akhir dari kedua skor grup tersebut. Skor akhir ini dapat ditentukan menggunakan tabel $\mathrm{C}$ untuk menghitung skor akhir, berikut ini adalah skor akhir dari grup A dan grup B.

Tabel 8. Skor REBA Grup C

\begin{tabular}{|c|c|c|c|c|c|c|c|c|c|c|c|c|c|}
\hline \multirow[b]{2}{*}{1} & \multicolumn{11}{|c|}{ Nilai Skor A } & & \\
\hline & 2 & 3 & 4 & 5 & 6 & 7 & 8 & 9 & 10 & 11 & 12 & & \\
\hline 1 & 1 & 1 & 2 & 3 & $\beta$ & 4 & 5 & 6 & 7 & 7 & 7 & 1 & \multirow{12}{*}{ 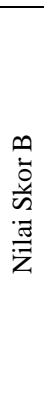 } \\
\hline 1 & 2 & 2 & 3 & 4 & 4 & 5 & 6 & 6 & 7 & 7 & 8 & 2 & \\
\hline 2 & 3 & 3 & 3 & 4 & $\$$ & 6 & 7 & 7 & 8 & 8 & 8 & 3 & \\
\hline 3 & 4 & 4 & 4 & 5 & 6 & 7 & 8 & 8 & . & 9 & 9 & 4 & \\
\hline 4 & 4 & 4 & 5 & 6 & 7 & 8 & 8 & 9 & 9 & 9 & 9 & 5 & \\
\hline 6 & 6 & 6 & 7 & 8 & 8 & 9 & 9 & 10 & 10 & 10 & 10 & 6 & \\
\hline 7 & 7 & 7 & 7 & 8 & 9 & 9 & 10 & 10 & 11 & 11 & 11 & 7 & \\
\hline 8 & 8 & 8 & 9 & 10 & 10 & 10 & 10 & 10 & 11 & 11 & 11 & 8 & \\
\hline 9 & 9 & 9 & 10 & 10 & 10 & 11 & 11 & 11 & 12 & 12 & 12 & 9 & \\
\hline 10 & 10 & 10 & 11 & 11 & 11 & 11 & 12 & 12 & 12 & 12 & 12 & 10 & \\
\hline 11 & 11 & 11 & 11 & 12 & 12 & 12 & 12 & 12 & 12 & 12 & 12 & 11 & \\
\hline 12 & 12 & 12 & 12 & 12 & 12 & 12 & 12 & 12 & 12 & 12 & 12 & 12 & \\
\hline
\end{tabular}

Skor Grup C berdasarkan tabel di atas adalah sebesar 6. Sedangkan untuk skor aktivitas, terjadi aktivitas yang berulang pada area yang relatif kecil, maka diberi tambahan skor 1 shingga total skor untuk grup $\mathrm{C}$ adalah $6+1=7$. Berdasarkan skor tersebut maka level risiko dari kegiatan Manual Material Handling tersebut masuk dalam level kategori sedang dan perlu segera dilakukan perubahan untuk postur kerja yang dilakukan.

Langkah berikutnya yaitu analisis dengan Quick Exposure Check (QEC) terhadap empat area tubuh yang terpapar pada risiko yang tertinggi untuk tejadinya work musculoskeletal disorders (WMSDs) pada seorang pekerja ataupun operator. Jawabanjawaban yang didapat dari kuesioner pada stasiun kerja Manual Material Handling kemudian akan dihitung nilai Exposure Score pada 4 bagian anggota tubuh dari operator pada stasiun kerja yang diteliti. Setelah didapatkan Exposure Score masing-masing anggota tubuh operator pada stasiun kerja yang diteliti, kemudian dilakukan rekapitulasi dari hasil perhitungan Exposure Score. 
Tabel 9. Rekapitulasi Exposure Score

\begin{tabular}{|c|c|c|}
\hline \multirow[b]{2}{*}{$\begin{array}{c}\text { Anggota Tubuh Yang } \\
\text { Diamati }\end{array}$} & \multicolumn{2}{|c|}{ Manual Material Handling } \\
\hline & $\begin{array}{c}\text { Operator } 1 \\
\text { (Rois) }\end{array}$ & $\begin{array}{l}\text { Operator } 2 \\
\text { (M. Yadil) }\end{array}$ \\
\hline Punggung (Statis) & - & . \\
\hline Punggung (Bergerak) & 52 & 52 \\
\hline Bahu/Lengan & 44 & 44 \\
\hline Pergelangan Tangan & 38 & 38 \\
\hline Leher & 14 & 14 \\
\hline Total Exposure Score & 148 & 148 \\
\hline
\end{tabular}

Selanjutnya adalah menghitung Exposure Level, digunakan untuk mengetahui tindakan apa yang harus dilakukan terkait dengan stasiun kerja yang diamati.

Tabel 10. Rekapitulasi Exposure Level

\begin{tabular}{cccccc}
\hline Stasiun Kerja & Operator & Nama Operator & Exposure Level & $\begin{array}{c}\text { Rata-Rata Exposure } \\
\text { Level }\end{array}$ & \multicolumn{1}{c}{ Tindakan } \\
\hline \multirow{2}{*}{ Manual Material Handlig } & 1 & Rois & $84,09 \%$ & $84,09 \%$ & $\begin{array}{l}\text { Dilakukan Penelitian dan } \\
\text { perubahan secepatnya }\end{array}$ \\
\hline
\end{tabular}

Dari tabel di atas dapat diketahui nilai rata-rata Exposure Level pada stasiun kerja Manual Material Handling adalah 84,09\%. Jika dilihat dalam tabel Action Level QEC maka tindakan yang dilakukan perlu penelitian dan perubahan secepatnya pada stasiun kerja tersebut.

Upaya yang dilakukan pada postur kerja adalah dengan menurunkan hasil skor dari metode RULA, REBA dan QEC yang saat ini dengan nilai skor usulan.

Tabel 11. Usulan Postur Kerja dengan Metode RULA

\begin{tabular}{ccccc}
\hline \multirow{2}{*}{ Faktor } & Kondisi Saat ini & \multicolumn{2}{c}{ Postur Usulan } \\
\cline { 2 - 5 } & Pergerakan & Skor & Pergerakan & Skor \\
\hline Lengan atas & $20^{\circ}-45^{\circ}$ & 2 & $0^{\circ}-20^{\circ}$ & 1 \\
Lengan bawah & $0^{\circ}-60^{\circ}$, ditambah gerakan ke kiri & 3 & $60^{\circ}-100^{\circ}$ & 1 \\
Pergelangan tangan & Lurus namun ditekuk dari garis tengah & 2 & Netral & 1 \\
Twist Pergelangan tangan & Ujung kisaran & 2 & Dalam jangkauan & 1 \\
Otot & Berulang $4 \mathrm{x} /$ menit & 1 & Berulang 4x/menit & 1 \\
Beban & $>20 \mathrm{~kg}$ & 2 & $>20 \mathrm{~kg}$ & 2 \\
Leher & $10^{\circ}-20^{\circ}$ & 2 & $0^{\circ}-10^{\circ}$ & 1 \\
Punggung & $20^{\circ}-60^{\circ}$, ditambah gerakan ke kiri & 4 & $0^{\circ}$ & 1 \\
Kaki & Lurus & 1 & Lurus & 1 \\
Otot & Berulang 4x/menit & 1 & Berulang 4x/menit & 1 \\
Beban & $>20 \mathrm{~kg}$ & 2 & $>20 \mathrm{~kg}$ & 2 \\
\hline & & & 4 \\
\hline
\end{tabular}

Tabel 12. Usulan Postur Kerja dengan Metode REBA

\begin{tabular}{ccccc}
\hline \multirow{2}{*}{ Faktor } & Kondisi Saat ini & \multicolumn{2}{c}{ Postur Usulan } \\
\cline { 2 - 5 } & Pergerakan & Skor & Pergerakan & Skor \\
\hline Lengan atas & $20^{\circ}-45^{\circ}$ & 2 & $0^{\circ}-20^{\circ}$ & 1 \\
Lengan bawah & $60^{\circ}-100^{\circ}$ & 1 & $60^{\circ}-100^{\circ}$ & 1 \\
Pergelangan tangan & $<15^{\circ}$ & 2 & $15^{\circ}$ & 1 \\
Leher & $0^{\circ}-20^{\circ}$ & 1 & $0^{\circ}-20^{\circ}$ & 1 \\
Punggung & $20^{\circ}-60^{\circ}$ & 3 & $0^{\circ}$ & 1 \\
Kaki & Tegak namun 1 kaki menjadi tumpuan & 2 & Tertopang dengan baik & 1 \\
Genggaman & Kurang baik & 2 & Kondisi baik & 0 \\
Beban & $>20 \mathrm{~kg}$ & 2 & $>20 \mathrm{~kg}$ & 2 \\
Aktivitas & Berulang 4x/menit & 1 & Berulang 4x/menit & 1 \\
\hline & Skor REBA & 7 & & 2 \\
\hline
\end{tabular}


Dari tabel di atas maka usulan perbaikan postur kerja tersebut masuk dalam risiko rendah dan perubahan dibutuhkan. Setelah melakukan usulan pada postur kerja dan juga melihat dari hasil metode QEC maka perlu dilakukan perbaikan pada stasiun kerja. Dibutuhkan alat bantu kerja Pallet Leveller Spring dan U-Lift Roll-In Lift Table yang digunakan untuk tempat pallet agar pekerja tidak perlu membungkuk saat meletakkan box tersebut.

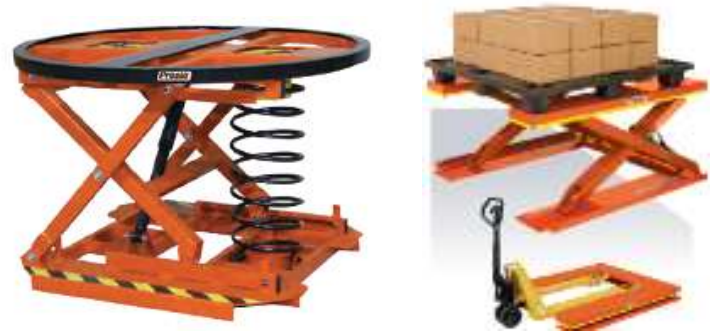

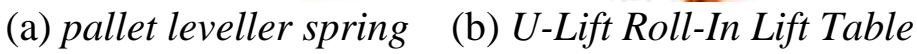
Gambar 3. Alat Bantu Kerja Usulan

Dengan menggunakan tambahan alat bantu kerja yang di usulkan, diharapkan terjadi perubahan sistem kerja pekerja. Hasil implementasi perbaikan kondisi lingkungan kerja dengan menambahkan alat bantu yaitu (a) pallet leveller spring bagi operator di bagian Manual Material Handling akan dievaluasi untuk melihat apakah beban kerja yang dirasakan oleh operator telah berkurang. Pallet leveler spring memiliki kapasitas beban 4500lbs dengan ketinggian maksimum 71,12 cm dengan ketinggian minimum 9 inch atau $22 \mathrm{~cm}$. Sedangkan (b) U-Lift Roll-In Lift Table ini memiliki kapasitas beban 2200lbs dengan ketinggian maksimum 31inch atau $79 \mathrm{~cm}$ dan minimum 3 inch atau 7,62 cm. Ukuran platform 48 inch $\times 53$ inch dengan penggerak motor tenaga 1 HP sehingga mengasilkan kecepatan naik turun 22 detik.

\section{KESIMPULAN}

Sikap pekerja bagian line robot pengemasan produk herbisida di PT. Petrokimia Kayaku Pabrik 3 pada proses Manual Material Handling masih kurang baik dalam menanggapi obyek situasi atau kondisi di sekitar tempat kerjanya. Selain itu sikap pekerja masih belum memberikan kesiapan untuk merespon yang sifatnya positif atau negatif terhadap obyek atau situasi. Nilai risiko tertinggi postur kerja pada operator Manual Material Handling pada line robot departemen pengemasan herbisida di PT. Petrokimia Kayaku Pabrik 3 berdasarkan metode RULA hasil skornya adalah 7 dengan tingkat risiko sangat berisiko sehingga perlu lakukan perubahan sekarang. Begitu juga dengan hasil analisis menggunakan metode REBA hasil skornya adalah 7 dengan level risiko sedang, sedangkan analisa menggunakan metode QEC diketahui nilai rata-rata Exposure Level pada stasiun kerja Manual Material Handling adalah 84,09\% maka tindakan yang dilakukan perlu penelitian dan perubahan secepatnya pada stasiun kerja tersebut. Usulan perbaikan yang dapat diberikan adalah sebagai berikut melakukan perbaikan postur kerja usulan dari hasil perhitungan yang dilakukan dengan metode REBA dari kondisi saat ini dengan skor 7 menjadi skor 2. Begitu juga perbaikan postur kerja usulan dari hasil perhitungan yang dilakukan dengan metode RULA dari kondisi saat ini dengan skor 7 menjadi skor 4. Sehingga pada proses Manual Material Handling dapat diberikan usulan berupa perbaikan postur kerja yang ergonomi yaitu operator berdiri dengan posisi tegak. Kemudian menambahkan alat bantu kerja berupa pallet leveller sping dan U-Lift Roll-In Lift Table agar operator tidak perlu membungkuk ketika meletakkan kardus ke atas pallet. Sehingga dengan usulan ini grand score RULA dapat turun menjadi 4 dan termasuk dalam 
kategori level risiko rendah (perubahan mungkin diperlukan), grand score REBA dapat turun menjadi 2.

\section{DAFTAR PUSTAKA}

[1] N. L. Kamaliyah, Sugiono, and W. Wijayanti. 2015. Peningkatan Performance System Pada Departemen Packaging Dengan Simulasi Proses Dan Redesign Workstation (Studi Kasus: CV. Segar Buah Hutama, Batu). J. Eng. Manag. Industial Syst., vol.3, no.1, pp. 55-61.

[2] Z. H. Zen. Perancangan Alat Material Handling Dengan Menggunakan Pendekatan Biomekanika Dan Postur Kerja Pada Bagian Pengepakan Pupuk Di CV. Bukitraya Laendrys Bukittinggi. Simp. Nas. Teknol. Terap. 2, pp. 72-83, 2014.

[3] R. R. Ardiliansyah, L. Handoko, and Wiediartini.2017. Analisis Tingkat Risiko Cedera MSDs pada Pekerjaan Manual Material Handling dengan Metode REBA dan RULA pada Pekerjaan Area Produksi Butiran PT. Petrokimia Kayaku. in Conference on Safety Engineering and Its Application, vol.1, no.1, pp. 61-66.

[4] N. Azizah and B. Aribowo. 2019. Evaluasi Postur Kerja Dengan Pendekatan Nordic Body Map Dan Rapid Body Assestment Untuk Mengurangi Resiko Cedera Pada Pekerja Di PT. Pertamina EP Asset 1 Jambi Field. in IENACO, pp. 8-15.

[5] B. R. Putera and A. Arvianto.2018. Usulan Perbaikan Postur Tubuh Pekerja Pada Kegiatan Perakitan (Assembly) Di PT. Hitachi Construction Machinery Indonesia Dengan Menggunakan Metode RULA (Rapid Upper Limb Assessment). Ind. Eng. Online J., vol. 6, no.4, 2018.

[6] Merulalia. 2010. Postur Tubuh yang Ergonomis Saat Bekerja. skripsi. Universitas Sumatera Utara.

[7] N. Lestari, P. Luh, and W. Susi. 2014. Pengaruh stretching terhadap keluhan muskuloskeletal pada perawat di ruang Ratna dan Medical Surgical RSUP Sanglah. Skripsi. Universitas Udayana

[8] A. Destha Joanda and D. B. 2017. Suhardi. Analisis Postur Kerja dengan Metode REBA untuk Mengurangi Resiko Cedera pada Operator Mesin Binding di PT. Solo Murni Boyolali. in Seminar dan Konferensi Nasional IDEC, pp. 72-76.

[9] B. Triyanto. 2012. Analisis Postur Kerja Menggunakan Metode Rula Dan Perancangan Ulang Stasiun Kerja Finishing Batik (Studi Kasus Pada UKM Pembuatan Batik Printing di Desa Pilang, Masaran, Sragen). Universitas Muhammadiyah Surakarta

[10] M. D. Novianti and S. Tanjung. 2016.Analisis Perbaikan Postur Kerja Operator Pada Prosespembuatan Pipa Untuk Mengurangi Musculoskeletal Disorders Dengan Menggunakan Metode Rula. in Seminar Nasional Sains dan Teknologi, 2016, November 2016, pp. 1-11.

[11] H. A. Nugraha, M. Astuti, and A. Rahman. 2013. Analisis Perbaikan Postur Kerja Operator Menggunakan Metode Rula Untuk Mengurangi Resiko Musculoskeletal Disorders (Studi Kasus pada Bagian Bad Stock Warehouse PT. X Surabaya). J. Rekayasa dan Manaj. Sist. Ind., vol.1, no.2, pp. p229-240

[12] T. Singh and J. Singh. Ergonomic evaluation of industrial tasks in Indian electronics industries. Int. J. Sci. Res., vol. 3, no.7, pp. 1056-1059, 2014.

[13] D. P. Restuputri. Metode REBA Untuk Pencegahan Musculoskeletal Disorder Tenaga Kerja. J. Tek. Ind., vol. 18, no.1, p. 19, 2017.

[14] M. Rahayu. Perbaikan Postur Kerja pada Operator Komputer dengan Menggunakan Metode Reba. J. Rekayasa Sist. Ind., vol.2, no.3, pp. 75-79, 2015.

[15] E. I. Yuslistyari and A. Adhadin. Perbaikan Postur Kerja Operator Pengelasan dengan Metode Quick Exposure Check (QEC). J. INTECH Tek. Ind. Univ. Serang Raya, 
vol.4, no.1, p. 17, 2018.

[16] A. Ilman, Yuniar, and Y. Helianty. Rancangan Perbaikan Sistem Kerja dengan Metode Quick Exposure Check (QEC). J. Online Inst. Teknol. Nas. Oktober, vol.1, no.2, pp. 2338-5081, 2013. 